\title{
“互联网 +”的高职《航空货运市场营销》课程改革与实践
}

Course Reform and Practice of Air Freight Marketing in Higher Vocational Colleges of "Internet +" 王金奉 张雅 李林 徐源璘

Xinchun Wang Ya Zhang Lin Li Yuanlin Xu

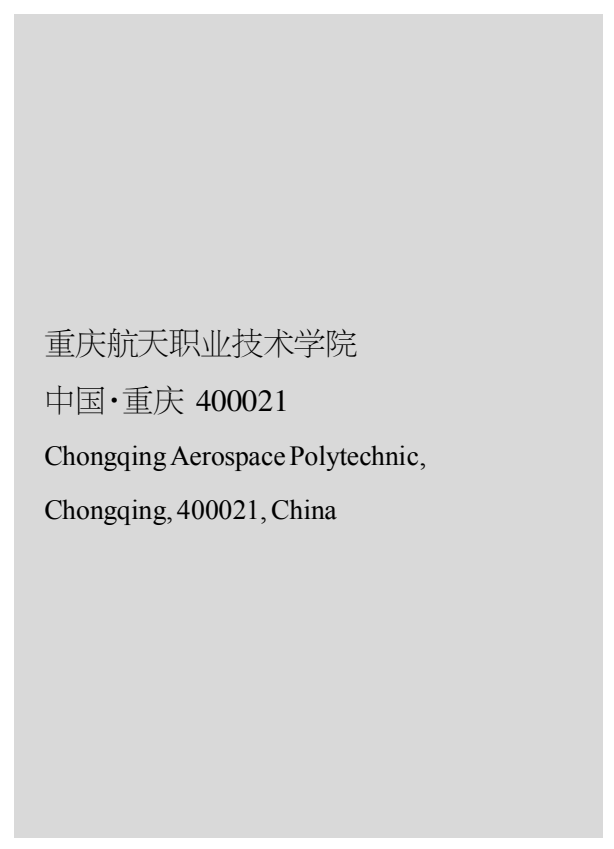

\section{1 “互联网 +”教育研究现状}

国际关于“互联网 + ”教育的研究, 大部分仅集中在关于 信息化时代下的“互联网+”学习方式,并没有对“互联网+教 育”时代背景下有效课堂的实施进行论证和研究。大多论述集 中在“互联网+教育”对教育领域发生的大变革, 以及“互联 网+”技术在教育教学上的运用，“互联网+”教育是一个大趋 势,而有效课堂的呼声也愈来愈高,如何把两者有机融合,让 互联网更好地服务于教育, 服务于课堂, 实现“能力本位, 学生 中心”具有理论和实践的双重研究意义,正因为如此, 本研究 拟在这方面有所突破。

\section{2 “互联网 +”的高职《航空货运市场营销》} 课程课堂教学改革的研究意义

通过对高职“互联网+”教学的现状调查, 探索其发展的 适合路径,力图将“互联网+”技术充分融合到高职《航空货运 市场营销》课程课堂教学中,打造高职《航空货运市场营销》有 效课堂教学模式。这样一方面丰富了高职课堂教学改革研究 的内容，为高职教师实施有效课堂教学提供了可供参考的范 本; 另一方面本课题通过重新设计高职《航空货运市场营销》
课程教学单元、变革教学手段、整合教学资源, 大力提高课堂 教学效果在很大程度上解决不断更新的人才培养理念与落后 的教学模式之间的矛盾。

\section{1 课程实施中出现理论与实践教学脱节, 人才} 培养目标与社会需求脱节等现象, 亟待重设课程标准

《国家中长期教育改革和发展规划纲要 (2010-2020)》指 出: 国家课程标准是教材编写、教学、评估和考试命题的依据, 是国家管理和评价课程的基础 [1]。应体现国家对不同阶段的 学生在知识与技能、过程与方法、情感态度与价值观等方面的 基本要求,规定各门课程的性质、目标、内容框架,提出教学建 议和评价建议。

高职课程标准是教师开展教学活动的基本教学文件, 是 规范教师教学内容的重要依据, 教师都应当遵守课程标准的 基本要求。目前表现出的问题就是制订课程标准仅仅是为了 人才培养工作水平评估的需要, 教师们也不按照课程标准的 要求授课,制订授课计划主要根据教材内容依次进行。课程标 准成了摆设, 教学内容和教学方法等取决于教师个人偏好, 且 现代社会的发展,课程实施中理论与实践教学脱节,人才培养

(下转第 6 页) 
教育理论与研究 Educational Theory and Research

\section{参考文献}

[1]郑金洲,程亮.中国教育学研究的发展趋向[J].教育研究,2005 (11):3-10

[2]石中英.本质主义、反本质主义与中国教育学研究 [J].教育研 究,2004(1):11-20.

[3]陈向明.实践性知识:教师专业发展的知识基础[J].北京大学教 育评论,2003(1):104-112.

[4]宁虹,钟亚妮.现象学教育学探析 [J].教育研究,2002(8):32-37.

[5]李英.体验:一种教育学的话语一一初探教育学的体验范畴 [J]. 教育理论与实践,2001(12):1-5.
[6]项贤明.教育:全球化、本土化与本土生长一一从比较教育学 的角度观照 $[\mathrm{J}]$. 北京师范大学学报(人文社会科学版),2001(2):32-41.

[7]王坦.合作教学的基本类型与理念析要 [J].山东教育科研,1999 (12):8-12.

[8]滕星.民族教育概念新析[J].民族研究,1998(2):23-30.

[9]叶澜.让课堂焕发出生命活力一一论中小学教学改革的深化 [J].教育研究, 1997(9):3-8.

[10]刘铁芳.必要与可能:教育学范式的打破与话语的更新 $[\mathrm{J}]$. 高 等师范教育研究,1997(5):20-24.

\section{（上接第 3 页）}

目标与社会需求脱节等现象越来越突出。所以亟须通过深度 研究现有的高职《航空货运市场营销》课程标准, 并在此基础 上结合高职物流专业人才培养方案和“互联网+”教育要求, 重新打磨更具有时代性的课程标准。

\section{2 课程并没有和“互联网 +”环境高度契合和} 紧密联系, 难以培养出时代性的创新型物流人才

2015 年 3 月，李克强总理在中华人民共和国第十二届 全国人民代表大会第三次会议《政府工作报告》中首次提出 “互联网+”行动计划, “互联网+”不仅深刻影响经济社会生 活, 更意味着思维方式的全新变革。随着“互联网+物流”的 不断推进, 高职院校也要与时俱进。打造基于 “互联网+”技 术的高职《航空货运市场营销》课程有效课堂, 要求高职 教师要熟悉和掌握各项 “互联网+”教学技术, 并在此基础 上将其融合到高职《航空货运市场营销》课程课堂教学中, 实现互联网+课堂教学的变革,培养出时代性的创新型物流 人才。

\section{3 高职《航空货运市场营销》的教学改革 实践研究}

本研究以高职《航空货运市场营销》课程为载体, 以该课 程课堂教学为抓手, 充分利用“互联网+”教学手段, 深度打磨 符合现代职业教育要求的课程标准, 重新构建适应当代高职 学生特征的课堂教学体系、不断丰富和完善课堂教学资源和 教学条件, 激发学生的学习主动性和积极性, 有效改善当前低 效的课堂教学, 为高职教学提供教学思路和方法, 促进专业教 师专业成长。

\section{1 基于“互联网 +”课程标准的研究}

课程标准是课堂教学设计的依据。打造基于 “互联网+” 技术的高职《航空货运市场营销》课程有效课堂, 必须仔细研 读现有的高职《航空货运市场营销》课程标准, 并在此基础上 结合高职专业人才培养方案和 “互联网+”教育要求, 重新完 善更具有时代性和实用性的课程标准。

\section{2 基于“互联网 +”教学设计的研究}

基于 “互联网+”教学模式改革的教学设计是 “有效课 堂” 能够成功实施的基础, 也是培养能够达到企业三维目 标人才的关键。因此设计完整性、规范性、有效性的教学设 计是非常有必要的, 并在此基础上将其融合到高职《航空 货运市场营销》课程课堂教学中, 实现 “互联网+”课堂教学 的变革。

\section{3 基于“互联网 +”教学资源的研究}

教学资源是课堂教学设计的素材。打造基于 “互联网+” 技术的高职《航空货运市场营销》课程有效课堂, 需要充分研 究 “互联网+”教学资源, 去粕存精, 优化整合, 并在此基础上 形成丰富的线上教学资源库。

\section{4 基于“互联网 +”的教改效果对比研究}

在实施基于 “互联网+”的“有效课堂”教改模式后, 将对 教学前后的整体效果进行对比分析, 主要以调查问卷的形式, 从学生对知识的掌握程度、学生对教学方式的接受程度、学生 对教学整体的满意率等进行调查。

\section{参考文献}

[1]中华人民共和国国务院.物流业发展中长期规划(2014-2020 年)[Z].2014-10-04. 